\title{
Effects of Toasting on Nutritional Value of Mesquite (Prosopis africana) Seeds and Its Utilization by Oreochromis niloticus Fingerlings
}

\author{
Shina Al-habeeb Aroyehun*1 $\quad$ Wilfred Olusegun Alegbeleye ${ }^{1} \quad$ Olubunmi Temilade Agbebi $^{1}$ \\ Adeyemi Mustafa Bamgbose ${ }^{2}$ \\ 1.Department of Aquaculture and Fisheries Management, Federal University of Agriculture, P.M.B 2240, \\ Abeokuta, Nigeria \\ 2.Department of animal nutrition, Federal University of Agriculture, P.M.B 2240, Abeokuta, Nigeria
}

\begin{abstract}
Nutritive value of mesquite (Prosopis african) seeds subjected to toasting processing method in the diet of Oreochromis niloticus fingerlings was studied in an 84-day feeding trials. One hundred and twenty all male fingerlings of $O$. niloticus $(5.53 \pm 0.01 \mathrm{~g})$ were stocked in triplicate and 4 iso-nitrogenous diets $(35 \%$ crude protein) were formulated using the toasted mesquite seed at $0 \%, 15 \%, 30 \%$ and $45 \%$ inclusion levels to replace soybean meal (SBM) in a completely randomized design (CRD). Proximate composition of the seed was significant $(P<0.05)$ on crude lipid, fiber and mineral content of mesquite seed. Essential amino acids profile were differently affected. The anti-nutritional factor tannin and phyate were slightly reduced. The highest weight gain $(5.32 \mathrm{~g})$, specific growth rate $\left(1.77 \%\right.$ day $\left.^{-1}\right)$, feed conversion efficiency $(0.71)$ protein efficiency ratio $(2.02$ $\%)$ and economic conversion ratio $(\$ 0.91 / \mathrm{kg})$ were observed in group fed diet I while diet 3 gave the least. Carcass proximate analysis showed high value for crude protein and ash content. Toasted mesquite seed meal could be exploited in the on-farm production of tilapia diet at $15 \%$ inclusion level.
\end{abstract}

Keywords: Mesquite seeds, toasting method, amino acids, nutrient utilization and Oreochromis niloticus.

DOI: $10.7176 / \mathrm{JBAH} / 9-14-02$

Publication date:July $31^{\text {st }} 2019$

\section{Introduction}

Oreochromis niloticus has become the fifty most cultured fish in world with production value of 3, 670260 tonnes behind Carp of which Nigeria is one of the largest producers in sub-Saharan Africa Atanda and Fagbenro (2017). However, tilapia production has been less outstanding owning to some of the major constraints deterring the development such as Low input technology (extensive culture system), Precocious breeding and high cost of feed.

Although, there has been deliberate effort either by the private sector or the government to improving the input technology and as well as breakthrough toward checking the precocious breeding of tilapia through genetically modified parent stock and administration of Methyl-testosterone (MT) feed, availability of cost effective and highly quality feed still remains a major constraint to tilapia production (Ajani et al. 2016). This is because of the rising cost of common protein ingredients such as fish meal and soybean.

Soybean meal is the most extensively used plant protein source in livestock diets as it has a high crude protein content and a well-balanced essential amino acids profile (Alegbeleye et al. 2012). However, inclusion of soybean in practical fish rations is constrained by its competitive use as a dietary protein source for human, livestock nutrition, use in bio-fuel, decline in national production and increasing costs have encouraged the search for a substitute (Jimoh et al. 2015). Hence, it is important to evaluate the nutritive value of other inexpensive under-utilized plant protein sources that would replace soybean meal such as mesquite seed.

Prosopis africana seed is among these abundant plants. It can be found growing wild in Nigeria and other parts of West Africa (Orwa et al. 2009). The fruits occur as pods which are dark brown cylindrical thick and hard shiny up to $15 \times 3 \mathrm{~cm}$ with woody walls compartmented; about 10 loose rattling seeds per pod (Orwa et al. 2009). Its common names include African mesquite, Iron tree, while its local Nigerian names are Kiriya (Hausa), Ayan (Yoruba) and Ubwa (Ibo) (Ogunshe et al. 2007). This study therefore, assess the effects toasting on the nutritive value of mesquite seed and to evaluate performance of the toasted seed meals in the diet of $O$. niloticus fingerlings.

\section{Materials and methods}

2.1 Feed procurement, processing and analysis

Mature mesquite seeds were purchased from a local market, in Gboko, Benue State, Nigeria. The other ingredients: soybean meal, groundnut cake, maize, fishmeal, vitamin and mineral premixes were obtained from a reputable livestock feed store at Fajol area, Abeokuta, Nigeria.

The seeds were toasted using a local heating system of stove at temperature between $80{ }^{\circ} \mathrm{C}$ and $120^{\circ} \mathrm{C}$ for 
15 minutes (Sotolu and Faturoti 2008). The toasted seed coats were removed by cracking the seeds and winnowing prior to milling by food blender (3D model) to produce toasted mesquite seed meal (TMS).

Toasted and raw seed samples were analysed for proximate composition, amino acid profile and antinutritional factor. The proximate composition was determined using methods described by Association of Official Analytical Chemists (AOAC 2005) while the amino acid profile was determined using the method described by Benitez (1989). The anti-nutrient analysis such as phytate and tannin were determined by the method of Graham (1992) and Wheeler and Ferrel (1971) respectively. The proximate composition of the fish carcass before and after the feeding trial were also determined according to AOAC (2005).

\subsection{Diet formulation}

Four iso-nitrogenous (35\% crude protein) and iso-caloric diets were formulated, with toasted mesquite seeds each replacing soybean meal at three levels (15\%, $30 \%$ and $45 \%)$ while the control diet was without mesquite seed meal, this is shown in table 3. Chromic oxide was used at $0.5 \%$ in all the experimental diets as an inert marker to determine the digestibility coefficient of nutrients in the diets. The ingredients were properly sieved to remove chaff and ensure homogenous size profile, mixed and pelleted through a $2 \mathrm{~mm}$ die using hand pelletizer (unbranded). The pellets were air dried and packed in properly labeled cellophane bags for use.

\subsection{Experimental system and fish}

The feeding trials were conducted in the fish hatchery of Aquaculture and Fisheries Department, College of Environmental Resources Management, Federal University of Agriculture Abeokuta, Nigeria.

One hundred and twenty all male fingerlings of $O$. niloticus $(5.53 \pm 0.01 \mathrm{~g})$ were obtained from a reputable farm, Lagos state. They were acclimated to experimental condition for seven days in a circular (2000 L) glass fibre tank prior to the feeding trial. Equal twelve plastic $50 \mathrm{~L}$ tanks, dimension $\left(49 \times 33.5 \times 33.5 \mathrm{~cm}^{3}\right)$ and water filled to $75 \%$ were randomly allocated to the four treatments. Ten fish per tank each were replicated thrice in a completely randomized design (CRD). The fish in each tank were batch weighed with the use of a sensitive weighing balance (METER TOLEDO FB602) to ensure uniformity in size in each tank and were covered with synthetic net to prevent fish from jumping out.

2.4 Fish maintenance and sample collection

Experimental fish in each tank were fed the experimental diet for period of 12 weeks at the rate of $3 \%$ body weight per day, shared between morning $(9.00 \mathrm{am})$ and evening $(4.00 \mathrm{pm})$. The fish were starved for $24 \mathrm{hrs}$ before the commencement of feeding trial. Fish were batch weighed weekly with a sensitive weighing balance (METER TOLEDO FB602) and the rations were adjusted according to weight gain. Water temperature, $\mathrm{pH}$ and dissolved oxygen were monitored in the course of the experiment weekly using standard methods. After feeding the fish for twelve weeks, Growth and nutrient utilization was evaluated on experimental fish according to Sotolu and Faturoti (2008). Fish faeces were collected daily for 2 weeks to the end of the experiment. One hour after the feeding, any feed and faeces present in the tanks was removed while fresh faeces produced by the fish after this period and before the next feeding were siphoned immediately in replicates to minimize leaching of nutrients into water. The collected faeces were filtered onto filter papers and dried. The faecal samples from each replicate tank were pooled according to treatment and stored in tagged cellophane bags in a freezer at $10^{\circ} \mathrm{C}$. Based on chromic oxide content of the diet, and nutrient content of the diet and faeces, apparent digestibility coefficients (ADCs) for feed protein were determined using the acid digestion method of Furukawa and Tsukahara (1966). The ADCs were calculated with the following formula:

$$
\operatorname{ADC}(\%)=100-\left[100 \times\left(\frac{\% \mathrm{Cr} 203 \text { in diet }}{\% \text { in faeces }} \times \frac{\% \text { nutrient in faeces }}{\% \text { nutrient in diet }}\right)\right]
$$

Based on the current market price of the ingredients in local market at the time of the study and the quantity that was required to make the different diets, the cost for $1 \mathrm{~kg}$ of each diet was calculated. Economic evaluation in terms of economic conversion ratio (ECR) and economic profit index (EPI) of substituting toasted mesquite seed meal for soybean meal in the diet of $O$. niloticus were calculated according to Moutinho et al. (2017).

ECK $(\mathrm{s} / \mathrm{kg})=\mathrm{F}(\mathrm{K} \times$ diet price $(\mathrm{s} / \mathrm{kg})$

EPI $(\$)=[$ Weight gain $(\mathrm{kg}) \times$ selling price $(\$ / \mathrm{kg})]-[$ weight gain $(\mathrm{kg}) \times \operatorname{diet}$ Price $(\$ / \mathrm{kg})]$

\subsection{Statistical analysis}

Results were analyzed using SPSS (Statistical Package Computer Software, 1988 version, Chicago Illinois, USA). Statistical analysis of data was done by one-way analysis of variance (ANOVA). Mean differences between treatments was tested for significance $(P<0.05)$ using Duncan's Multiple Range. 


\section{Results}

There were significant differences $(P<0.05)$ in crude lipids, fibre and mineral contents in the proximate composition (Table 1). Lower values were recorded for both Tannin and Phyates in toasted seeds. Higher values were obtained in essential amino acid (EAA) of toasted compare to toasted Soybean. Lower values were recorded for methionine and tryptophan of toasted compared to raw seeds (Table 2).

No pathological signs were observed during the trial, and mortality was very low and unaffected $(P<0.05)$ by the dietary treatments (Table 4). Final body weight, weight gain and specific growth rate of fish fed diet 3 were significantly difference $(P<0.05)$ from those fed the control diet (Table 4). However, those fed diet 1 and 2 were similar with those fed control diet $(P>0.05)$. Likewise, similar $(P>0.05)$ feed conversion ratio and protein productivity ratio were observed for control and diet 1 groups. Despite the highest voluntary feed intake, fish fed diet 3 obtained the lowest $(P<0.05)$ growth performance and feed efficiency. At the end of the trial, carcass composition were significantly affected as showed in Table 5. The feed cost of producing one kilogram of fish expressed as economic conversion ratio (ECR) for diet 1 was significantly $(P<0.05)$ lower than the control diet and all other diets (Table 6).

Table 1: Proximate composition and anti-nutritional factor of mesquite seeds (\%)

\begin{tabular}{|c|c|c|c|}
\hline Parameters & \multicolumn{2}{|c|}{ Toasted } & Raw \\
\hline Moisture & \multicolumn{2}{|c|}{$13.55 \pm 0.35^{\mathrm{a}}$} & $14.80 \pm 0.40^{\mathrm{a}}$ \\
\hline Crude protein & \multicolumn{2}{|c|}{$37.89 \pm 1.58^{\mathrm{a}}$} & $35.10 \pm 1.07^{\mathrm{a}}$ \\
\hline Crude lipid & \multicolumn{2}{|c|}{$03.46 \pm 0.05^{\mathrm{b}}$} & $04.02 \pm 0.01^{\mathrm{a}}$ \\
\hline Ash & \multicolumn{2}{|c|}{$04.25 \pm 0.06^{\mathrm{a}}$} & $04.00 \pm 0.15^{\mathrm{b}}$ \\
\hline Crude fibre & \multicolumn{2}{|c|}{$05.41 \pm 0.25^{\mathrm{b}}$} & $07.79 \pm 0.07^{\mathrm{a}}$ \\
\hline NFE* & \multicolumn{2}{|c|}{$35.44 \pm 1.67^{\mathrm{b}}$} & $34.29 \pm 1.27^{b}$ \\
\hline Calcium & \multicolumn{2}{|c|}{$2.42 \pm 0.10^{\mathrm{a}}$} & $2.11 \pm 0.07^{\mathrm{b}}$ \\
\hline Phosphorus & \multicolumn{2}{|c|}{$2.55 \pm 0.13^{\mathrm{a}}$} & $2.31 \pm 0.04^{\mathrm{a}}$ \\
\hline Tannin & \multicolumn{2}{|c|}{2.4} & 2.8 \\
\hline Phyate & \multicolumn{2}{|c|}{3.0} & 3.6 \\
\hline \multicolumn{4}{|c|}{$\begin{array}{l}\text { Means on the same row with the different superscript are significantly different } P<0.05 \text { Key NFE*: nitrogen } \\
\text { free extract. }\end{array}$} \\
\hline \multicolumn{4}{|c|}{ Table 2: Amino acids Profile ( $\mathrm{g} / 100 \mathrm{~g}$ protein) of toasted Mesquite Seeds } \\
\hline Amino acid & Toasted & Raw & Toast Soybean* \\
\hline Arginine & 5.76 & 5.59 & 4.48 \\
\hline Histidine & 2.04 & 2.24 & 3.00 \\
\hline Isoleucine & 2.95 & 3.21 & 2.32 \\
\hline Leucine & 7.70 & 7.29 & 6.00 \\
\hline Lysine & 5.04 & 4.56 & 3.60 \\
\hline Methionine & 1.76 & 1.82 & 0.88 \\
\hline Phenylalanine & 3.81 & 3.99 & 3.06 \\
\hline Threonine & 3.55 & 3.38 & 2.80 \\
\hline Tryptophan & 0.60 & 1.00 & - \\
\hline Valine & 3.68 & 3.67 & 2.85 \\
\hline \multicolumn{4}{|l|}{ Non-essential } \\
\hline Tyrosine & 3.61 & 3.10 & 2.63 \\
\hline Proline & 3.25 & 3.25 & 3.08 \\
\hline Cystine & 0.60 & 0.85 & 0.70 \\
\hline Alanine & 4.85 & 4.17 & 3.04 \\
\hline Glutamic acid & 12.72 & 12.26 & 14.94 \\
\hline Glycine & 5.03 & 4.51 & 3.35 \\
\hline Serine & 2.48 & 3.46 & 1.90 \\
\hline Aspartic acid & 10.62 & 9.02 & 10.49 \\
\hline
\end{tabular}

*Ari et al. (2012) 
Table 3: Formulation and proximate composition of the experimental diets

\begin{tabular}{|c|c|c|c|c|}
\hline & Control & Diet 1 & Diet 2 & Diet 3 \\
\hline \multicolumn{5}{|l|}{ Ingredients $(\%)$} \\
\hline Maize & 27.91 & 27.41 & 27.41 & 27.41 \\
\hline Fish meal & 16.02 & 16.15 & 16.15 & 16.15 \\
\hline Groundnut cake & 16.02 & 16.15 & 16.15 & 16.15 \\
\hline Soybean Meal & 32.05 & 27.45 & 22.60 & 17.76 \\
\hline Toasted MSM ${ }^{1}$ & - & 4.84 & 9.68 & 14.53 \\
\hline Vegetable oil & 5 & 5 & 5 & 5 \\
\hline Vit/ Min premix & 0.5 & 0.5 & 0.5 & 0.5 \\
\hline Methionine & 0.5 & 0.5 & 0.5 & 0.5 \\
\hline Lysine & 0.5 & 0.5 & 0.5 & 0.5 \\
\hline Starch & 0.25 & 0.25 & 0.25 & 0.25 \\
\hline Common salt & 0.25 & 0.25 & 0.25 & 0.25 \\
\hline Dicalciumphosphate & 0.5 & 0.5 & 0.5 & 0.5 \\
\hline Chromic oxide & 0.5 & 0.5 & 0.5 & 0.5 \\
\hline \multicolumn{5}{|l|}{ Proximate analysis $(\%)$} \\
\hline Moisture & 9.29 & 9.57 & 9.39 & 9.22 \\
\hline Crude lipid & 10.88 & 11.00 & 10.49 & 10.66 \\
\hline Ash & 10.68 & 10.23 & 10.37 & 10.29 \\
\hline Crude protein & 36.01 & 35.18 & 35.52 & 35.79 \\
\hline Crude fibre & 4.08 & 4.44 & 5.42 & 5.00 \\
\hline Nitrogen free extract & 29.08 & 29.58 & 28.82 & 29.05 \\
\hline Gross energy $\left(\mathrm{KJg}^{-1}\right)^{2}$ & 17.42 & 17.35 & 17.11 & 17.27 \\
\hline
\end{tabular}

${ }^{1}$ Mesquite seed meal, ${ }^{2}$ Calculated using the factors: carbohydrates, $4.1 \mathrm{kcal} \mathrm{g}^{-1}$; protein, $5.5 \mathrm{kcal} \mathrm{g}^{-1}$ and lipids, $9.1 \mathrm{kcal} \mathrm{g}^{-1}$ (New 1987) and transformed to kJ using the factor 4.184.

Table 4: Growth performance and nutrient utilization of $O$. niloticus fed experimental diets.

\begin{tabular}{|c|c|c|c|c|c|}
\hline \multicolumn{2}{|l|}{ Parameters } & Control & Diet 1 & Diet 2 & Diet 3 \\
\hline \multicolumn{2}{|c|}{ Initial weight (g) } & $5.53 \pm 0.02^{\mathrm{a}}$ & $5.54 \pm 0.10^{\mathrm{a}}$ & $5.53 \pm 0.01^{\mathrm{a}}$ & $5.52 \pm 0.01^{\mathrm{a}}$ \\
\hline \multicolumn{2}{|c|}{ Final weight (g) } & $10.60 \pm 0.70^{\mathrm{a}}$ & $10.86 \pm 0.40^{\mathrm{a}}$ & $10.43 \pm 0.34^{\mathrm{a}}$ & $10.31 \pm 0.08^{\mathrm{b}}$ \\
\hline \multicolumn{2}{|c|}{ Weight gain $(\mathrm{g})$} & $5.08 \pm 0.60^{\mathrm{a}}$ & $5.32 \pm 0.38^{\mathrm{a}}$ & $4.89 \pm 0.34^{\mathrm{a}}$ & $4.78 \pm 0.09^{\mathrm{b}}$ \\
\hline \multicolumn{2}{|c|}{ Survival rate $(\%)$} & $100 \pm 0.00^{\mathrm{a}}$ & $96.67 \pm 5.76^{\mathrm{a}}$ & $100 \pm 0.00^{\mathrm{a}}$ & $100 \pm 0.00^{\mathrm{a}}$ \\
\hline \multicolumn{2}{|c|}{ Feed intake $(\mathrm{g})$} & $7.35 \pm 0.26^{\mathrm{c}}$ & $7.51 \pm 0.16^{\mathrm{c}}$ & $7.65 \pm 0.38^{\mathrm{ab}}$ & $8.08 \pm 0.38^{\mathrm{a}}$ \\
\hline \multicolumn{2}{|c|}{ Specific growth rate $\left(\%\right.$ day $\left.^{-1}\right)$} & $1.74 \pm 0.00^{\mathrm{a}}$ & $1.77 \pm 0.07^{\mathrm{a}}$ & $1.70 \pm 0.07^{\mathrm{a}}$ & $1.66 \pm 0.05^{\mathrm{b}}$ \\
\hline \multicolumn{2}{|c|}{ Feed conversion ratio } & $1.45 \pm 0.04^{\mathrm{b}}$ & $1.42 \pm 0.09^{b}$ & $1.56 \pm 0.17^{\mathrm{ab}}$ & $1.69 \pm 0.09^{\mathrm{a}}$ \\
\hline \multicolumn{2}{|c|}{ Feed Efficiency ratio } & $0.69 \pm 0.02^{\mathrm{a}}$ & $0.71 \pm 0.04^{\mathrm{a}}$ & $0.64 \pm 0.07^{\mathrm{bc}}$ & $0.59 \pm 0.04^{b}$ \\
\hline \multicolumn{2}{|c|}{ Protein Efficiency ratio (\%) } & $1.97 \pm 0.05^{\mathrm{a}}$ & $2.02 \pm 0.12^{\mathrm{a}}$ & $1.82 \pm 0.20^{\mathrm{bc}}$ & $1.69 \pm 0.11^{\mathrm{c}}$ \\
\hline \multicolumn{2}{|c|}{ Protein productivity value $(\%)$} & $0.66 \pm 0.03^{\mathrm{a}}$ & $0.64 \pm 0.02^{\mathrm{a}}$ & $0.47 \pm 0.03^{\mathrm{b}}$ & $0.18 \pm 0.02^{\mathrm{c}}$ \\
\hline \multicolumn{2}{|c|}{ Apparent dry Matter digestibility (\%) } & $77.88 \pm .03^{\mathrm{ab}}$ & $78.58 \pm 1.05^{\mathrm{ab}}$ & $78.86 \pm .25^{\mathrm{a}}$ & $78.46 \pm 1.30^{\mathrm{ab}}$ \\
\hline \multicolumn{2}{|c|}{ Apparent protein digestibility $(\%)$} & $83.23 \pm 0.31^{\mathrm{a}}$ & $80.27 \pm .17^{\mathrm{b}}$ & $79.40 \pm .51^{\mathrm{bc}}$ & $78.13 \pm .15^{\mathrm{c}}$ \\
\hline \multicolumn{6}{|c|}{ Means on the same column with the different superscript are significantly different $(P<0.05)$} \\
\hline Parameters & Initial & Control & Diet 1 & Diet 2 & Diet 3 \\
\hline Moisture & $76.23 \pm .34^{\mathrm{a}}$ & $73.56 \pm .96^{\mathrm{a}}$ & $75.35 \pm .20^{\mathrm{a}}$ & $73.57 \pm 1.1^{\mathrm{a}}$ & $75.50 \pm .45^{\mathrm{a}}$ \\
\hline Protein & $52.22 \pm .04^{\mathrm{d}}$ & $53.85 \pm .05^{\mathrm{a}}$ & $53.90 \pm .00^{\mathrm{a}}$ & $53.50 \pm 0.0^{\mathrm{c}}$ & $53.65 \pm 0.0^{\mathrm{b}}$ \\
\hline Lipid & $8.70 \pm 0.25^{\mathrm{a}}$ & $8.39 \pm 0.2^{b}$ & $7.22 \pm .03^{\mathrm{d}}$ & $7.22 \pm .03^{\mathrm{d}}$ & $7.59 \pm 0.08^{c}$ \\
\hline Ash & $10.53 \pm 0.08^{d}$ & $11.22 \pm .02^{\mathrm{c}}$ & $11.30 \pm .02^{\mathrm{c}}$ & $11.76 \pm .11^{\mathrm{b}}$ & $13.49 \pm .01^{\mathrm{a}}$ \\
\hline
\end{tabular}

Means on the same row with the different superscripts are significantly different $(P<0.05)$

Table 6: Economic analysis of $O$. niloticus fingerlings fed experimental diets

\begin{tabular}{lllll}
\hline Parameters & Control & Diet 1 & Diet 2 & Diet 3 \\
\hline Diet price $(\$ / \mathrm{Kg})$ & 0.93 & 0.91 & 0.86 & 0.81 \\
ECR $(\$ / \mathrm{Kg})$ & $1.35^{\mathrm{b}}$ & $1.29^{\mathrm{c}}$ & $1.34^{\mathrm{b}}$ & $1.37^{\mathrm{a}}$ \\
EPI & 0.004 & 0.004 & 0.004 & 0.004 \\
\hline
\end{tabular}

Means on the same row with the different superscripts are significantly different $(P<0.05)$ 


\section{Discussion}

The crude protein content of raw mesquite seeds $(35.10 \%)$ (Table 1) were found to be higher which is comparable to other leguminous plants such as locust bean $(28.54-32.40 \%)$ Hassan and Umar, (2005), baobab seeds (20-36 \%) and sunflower seeds (24.4-36.7\%) Prince et al. (2017). Thus this higher level of protein content is a pointer to it nutritional significance, since moderate intake of these seeds will greatly increase the total dietary protein intake of the fish. The measurable increase in crude protein of toasted mesquite seed meal compared to the raw sample thus contrast with the observations of Southgate (2000) but agreed with the observation of Doss et al. (2011); Olanipekun et al. (2015) reported that this could be due to breakdown of crude protein to amino acids. The raw sample had the highest value $(7.79 \%)$ for crude fibre and this was found to be comparable with other legumes such as Jack bean (7.37\%) (Doss et al. 2011). Toasting also improved the mineral content of the seed meal compared to raw sample, this disagreed with the observation of Kankengi et al. (2003).

The amino acid concentration in the toasted mesquite seeds with respect to Histidine $(2.04 \mathrm{~g} / 100 \mathrm{~g})$, Isoleucine (2.95 g / $100 \mathrm{~g})$, Methionine (1.76 g / $100 \mathrm{~g})$, Phenylalanine (3.81g / $100 \mathrm{~g})$ and Tryptophan $(0.60 \mathrm{~g} /$ $100 \mathrm{~g}$ ) values were lower compared to the raw sample (Table 2). This could be traced to heating which is known to denature proteins or irreversible combination of amino acids with other nutrients (Southgate 2000).

In this study, a marked reduction in the level of phytic acid and tannin of toasted mesquite seed is similar to some previous studies where processing method was effective in reducing it (Mukhopadhyay and Ray 2001); (Alegbeleye and Olude 2009). This suggests that the observed anti-nutritional factors in toasted mesquite seeds will have no effect on the fish.

The performance of $O$. niloticus at the end of the experiment was influenced primarily by the amount of toasted mesquite seed meal in the diet. Growth and nutrient utilization were significantly high $(P<0.05)$ in the group fed diet 1 control and diet 2 in contrast to the group fed diet 3 . This shows that partial $(10 \%-15 \%)$ replacement of soybean with toasted mesquite meal did not compromise the fish growth. However, higher replacement level showed a significant $(P<0.05)$ reduction in growth and nutrient utilization as revealed in the group fed diet 3. Mesquite seed has been shown (Table 1) to contain high level of fiber. These are not digestible by monogastric animals, with some components having anti-nutritional effects in fish (Chou et al. 2004). The low growth and nutrient utilization in fish fed diet 3 could be attributed to an increase in the fiber content of the diet.

Carcass proximate analysis showed high value for crude protein and ash. The highest ash content and high crude lipid obtained in diet 3, could be due to availability of sufficient energy in the diet (Ajani et al. 2016). The high crude protein obtained in diet 1 which was not significantly different $(P>0.05)$ from control agreed Abdelghany (2003), who reported that diets containing soybean meal for $O$. niloticus increased body protein.

Replacement of SMB with toasted MSM appears to be economically feasible. The cost of formulating present diets for $O$. niloticus was reduced as toasted MSM levels increased and this was in consonant with previous studies where conventional feed stuff were partial replaced with meat and bone meat in diets for gilthead seabream (Sparus aurata) juveniles (Moutinho et al. 2017).

\section{Conclusions}

This study demonstrated that mesquite seed contains high protein value and appreciable quantity of minerals, and toasting significantly reduced $(P<0.05)$ the levels of tannins and phytates in the seed. Therefore, toasted mesquite seed meal could be exploited by the small holder farmers at $15 \%$ inclusion level in production of fish feeds to reduce the cost of production of tilapia diets. To explore higher inclusion levels further studies on other processing methods are recommended since toasting alone seems not to be effective in removing crude fibre content.

\section{References}

Abdelghany, A.E. (2003). Replacement of herring fish meal by soybean flour in practical diets for red tilapia, Oreochromis niloticus x O. mossambicus, grown in concrete tanks. J. Applied Aquaculture. 14: 6987.

Ajani, E.K, Orisasona, O., Omitoyin, B.O. and Osho, E.F. (2016). Total Replacement of fishmeal by soybean meal with or without methionine fortification in the diets of Nile Tilapia, Oreochromis niloticus. Journal of Fisheries and Aquatic Science, 11: 238-243.

Alegbeleye, W. O. and Olude, O. (2009). An evaluation of diets containing various levels of fermented cottonseed hull on digestibility and growth of Nile tilapia (Oreochromis niloticus) fingerlings. Asian Fish Science, 22:857-866.

Alegbeleye, W. O., Obasa, S. O., Olude, O. O., Moronkeji, T. and Abdulraheem, I. (2012). Growth Performance and Nutrient Utilization of African Mud Catfish (Clarias gariepinus) Fingerlings fed Different Levels of Fermented Pigeon Pea (Cajanus cajan) meal. Israeli Journal of Aquaculture - Bamidgeh, 64.731, 8. 
AOAC. (2005). Official Methods of Analysis. 18 th Edition Association of Official Analytical Chemists, Maryland, Washington; D. C. USA., pp: 25-26.

Atanda, A.N. and Fagbenro, O.A. (2017). Social and economic performance of tilapia farming in Nigeria. In J. Cai, K.K. Quagrainie \& N. Hishamunda, eds. Social and economic performance of tilapia farming in Africa, pp. 113-125. FAO Fisheries and Aquaculture Circular No. 1130. Rome, Italy.

Ari, M.M, Ayanwale, B.A, Adama, T.Z and Olatunji, E.A. (2012). Evaluation of chemical and anti-nutritional factors of (ANFs) Levels of different thermally processed soybeans. Asian journal of Agricultural research.6 (2):91-98.

Benitez, L. V. (1989). Amino Acid and fatty acid profiles in aquaculture nutrition studies, p. 23- 35. In S.S. De Silva (ed.) Fish Nutrition Research in Asia. Proceedings of the Third Asian Fish Nutrition Network Meeting. Asian fish. Society Special Publication. 4, 166 p. Asian Fisheries Society, Manila Philippines.

Chou, R.L., B.Y. Her, M.S. Su, G. Hwang, Y.H. Wu and H.Y. Chen. (2004). Substituting fish meal with soybean meal in diets of juvenile cobia Rachycentron canadum. Aquaculture, 229: 325-333.

Doss, A., Pugalenthi, M., Vadivel, V. G.,Subhashini, G. and Anitha Subash, R. (2011). Effects of processing technique on the nutritional composition and antinutrients content of underutilized food legume Canavalia ensiformis L. International Food Research Journal 18(3): 965-970.

Furukawa, A. and Tsukahara, H. (1966). On the acid digestion method for the determination of chromic oxide as the index substance in the study of fish feed. Bulletine of Japan Sociology and Sciencie Fish; 32:502e4.

Graham, H.D. (1992). Stabilization of the Prussian blue colour in the determination of polyphenols. Journal of agriculture and food chemistry. 40 (5) 801-805.

Jimoh, W. A., Sodamola, M. O., Adebayo, M. D., Banjo, O. T., Ayeloja, A. A. and Adeleke, A. B. (2015). Histological changes in the liver and kidney of Clarias gariepinus fed Chrysophyllum albidum seedmeal as maize replacer. International Journal of Zoological Research, 11: 29-36.

Hassan, L.G. And Umar, K.J. (2005). Protein and Amino Acids Composition of African Locust Bean (Parkia biglobosa). Tropical and Subtropical Agroecosystems, 5: 45 - 50.

Kankengi, A. M. V., Shen, M. N., Sarwart, S. V. and Fujihara, T. (2003). Can Moringa oleifera be used as protein supplement to ruminant diet? Asian-Australian Journal of Animal Science, 18(1): 42-47.

Moutinho S, Martínez-Llorens S, Tomás-Vidal A, Jover-Cerdá M, Oliva-Teles A, Peres H. (2017). Meat and bone meal as partial replacement for fish meal in diets for gilthead seabream (Sparus aurata) juveniles: Growth, feed efficiency, amino acid utilization, and economic efficiency. Aquaculture 468, 271-277.

Mukhopadhyay, N and Ray, A.K. (2001). Effects of amino acid supplementation on the nutritive quality of fermented linseed meal protein in diets for rohu Labeo rohita fingerlings. Journal of Applied Ichthyology $17,220-226$.

New, M.B. (1987). Feed and feeding of fish and shrimp. A Manual on the Preparation of Compound Feeds for Shrimp and Fish in Aquaculture. FAO, Rome, Italy.

Ogunshe, A. A. O., Omotosho, M. O. and Ayanshina, A. D. V. (2007). Microbial studies and biochemical characteristics of controlled fermented Afiyo-a Nigerian fermented food condiment from Prosopis africana (Guill and Perr.) Taub. Pakistan Journal of Nutrition, 6: 620627.

Olanipekun, O.T., Omenna, E.C., Olapade, O.A., Suleiman, P. and Omodara, O.G. (2015). Effect of boiling and roasting on the nutrient composition of kidney beans seed flour. Sky Journal of Food Science, 4(2) 024 029.

Orwa, C., Mutua, A., Kindt, R., Jamnadass, R. and Anthony, S. (2009). Agroforestree Database: A tree reference and selection guide version. www.worldagroforestry.org.

Sotolu A. O. and Faturoti E. O. (2008). Digestibility and nutritional values of differently processed Leucaena leucocephala (lam. de wit) seed meals in the diet of African catfish (Clarias gariepinus). Middle-East Journal of Scientific Research 3 (4): 190-199.

Southgate, D.A.T. (2000). Food processing. In: Human Nutrition and Dietetics. (Eds.) Garrow, J.S., James, W.P.T and Ralp, A.; Churchill livingstone. Edinburg. $10^{\text {th }}$ edn, 397- 409.

Prince C., Tinashe k. and Never A. (2017). Baobab seeds as an alternative protein source in poultry feed. Scientific Journal of Review 6(1) 509-518.

Wheeler, E. L. and Ferrel, R. E. (1971). A method for phytic acid determination in wheat and wheat fractions. American Association of Cereal Chemists. 48, 312 - 20. 